\title{
Literature and Culture During and After the Covid-19: A Thought
}

\author{
Debabrata Adhikary
}

Assistant Professor, Department of English, Hooghly Women's College, Pipulpati, Chinsurah, Dist: Hooghly, West Bangal, India

\begin{abstract}
The endeavour of the present paper is to trace the outlook of literature, and, also of the human culture, during and after the Covid-19 pandemic. Has literature lost its value and utility in the current troubled situation? Has Covid-19 announced the death-knell of literature and literary culture, in a country where they were fast receding; at least for quite a considerable period now? Or, should literature rather rise up to the occasion, and, try to evolve in a new form and manner to the human society; provide us with a new message, and shower us with new hope and new light amid the general gloom? If it does, then what can be the desired form/s? Is the concept of the 'alienating self' something new in literature and human culture, or, has it already been introduced to us through several literary texts? What are the possible advantages and drawbacks of self-alienation in society and human culture? How should the publication industry/publication market survive in such a critical time? If social distancing is the new norm and form of cultural (or, non-cultural) negotiations in an already distanced society, then, should literature try to focus on that in the present scenario? But how?
\end{abstract}

Keywords - literature, alienation, social distancing, regional, cocoon, self-protective, other etc.

\section{INTRODUCTION}

The objective of the present paper is to take a look at the nature and features of what we know as literature or literary activity during, or, after the Covid-19 scenario. If a literary artist is an integral part of the society he is born into, or, if literature is abody/product of the social exchanges, and negotiations of various sorts among itsdifferent characters, then what should literature look like in the present situation when social distancing, or shunning/banning the social becomes the new norm? Can literature or literary activities thrive in such a situation at all, or, should it be completely discarded as a mere luxury? Can we but say that the Covid-19 has heralded in the birth of a completely new era, or, has caused a rupture from the earlier, normalised social set-up? Is it that such alienation/isolation and the lack of communication between humans have been something new, or, uncommon, and, there has not been ample reflection of it in literatures/literary works of the pre-Covid period? Is it that we already somewhere became distanced from each other, whether inside home/family, or, outside home/family, and, the Covid-19 is a just continuation, an extreme effect of the same, although in an unexpected way?

\section{ANALYTICAL DISCUSSION}

But even if we became socially and mentally distanced earlier, at least we still had the luxury of venturing out at our liberty, and, mixing up with people of various sections and classes, which is crucial for composing any literary work. But since that is stopped, what should be the form of a literary work now? Should we now, like the Romantic poets of English literature, drown ourselves with essential thought/speculation on nature, or, some objects of nature, in order to forget the surrounding reality, which is only full of the 'weariness, the fever, and the fret', and, where men can only'sit and hear each other groan'? Should we, like Wordsworth, look at Nature as the inspiring/encouraging deity in such troubled time like this:

If this

Be but a vain belief, yet, oh! How oft-

In darkness and amid the many shapes

Of joyless daylight; when the fretful stir

Unprofitable, and the fever of the world,

Have hung upon the beatings of my heart-

How oft, in spirit, have I turned to thee,

O sylvan Wye! thou wanderer through the woods, 
How often has my spirit turned to thee! (76)

Or, should we rather, pin our all hopes on the mighty west wind, or the western wind, as Shelley has done in his 'Ode to the West Wind', to deliver us from the current troubled times, when the number of the Corona-infected patients is increasing in our country as well as in the whole world, and, every day we are touching new records, with numerous deaths being registered on a single day:

; I would ne'er have striven

As thus with thee in prayer in my sore need.

Oh, lift me as a wave, a leaf, a cloud!

I fall upon the thorns of life! I bleed!

A heavy weight of hours has chained, and bowed

One too like thee: tameless, and swift, and proud. (99)

Is it possible for us to say triumphantly in today's scenario(by keeping our all faith essentially on the west wind) that, if 'Winter comes, can Spring be far behind?' Or, is this rather too much of an escapist way to fly away from the present problems that Corona virus poses to us? Is poetry the only sustainable form of literature now, or, should it be so; keeping in mind the polyphony or the dialogic interaction of characters between different caste, class, race, religion, ethnicity, and gender being an impossibility in present scenario? If that is so, then what mode/s of poetry should fit the bill? Can drama be another productive form in the Covid-19 situation? Is novel completely unsuitable in the present situation?Should literature/s now essentially aim atcontaining and spreading the optimistic maxims (that ultimately one day or other Corona virus will be ultimately removed from the human society, and, everything will be normal)? But, would that not be too much of an idealistic comment, considering the current situation that we are in, with literature becoming a vehicle of remote possibility? Or, should literature/literary work rather try to grapple with the present situation as it is and try to uphold that? For, after all there is really nothing to panic. We just need to be aware. We just need to remain conscious. And, if we remain alert, if we remain vigilant, if we follow the government guidelines on a regular basis, then obviously we can protect ourselves as also our family; with no questions arising as to why we cannot consider the present situation as normal. Perhaps, this corona-normal would be our new normal. Yes, our daily lifestyle would have to undergo a sea-change for that. We need to avoid all addas, unnecessary gatherings, social functions; would have to be extra cautious regarding our daily hygiene,about the daily cleansing/cleaning and washing; which we were used to do otherwise. Yes, probably earlier, we were too much dependent on our maids or domestic helps for doing our daily chores (like sweeping and cleaning the floor, washing our clothes, or cooking etc) which we would not be from now on. In other words, we would be more selfdependent/self-reliant now because of the Corona phobia, which is good. Also, leaving aside the good-bad question, this aspect of self-dependence and self-maintenance/selfsustenance would and should continue to affect the literature/s composed during and after the Covid-19 period, for quite some time; whether in a direct or in an indirect measure. But the question is if we can maintain our personal daily hygiene, then there is no question as to why we have to be unnecessarily phobic about the whole situation and why literature cannot thrive in such a situation. Rather in absence of the voluminous, page after page written literature, which seems to be quite a luxury now, we can have now placards, posters, banners of different sorts exhibiting different kinds of signs, symbols, word-diagrams, picture-diagrams, illustrations; which can serve as our new texts containing various public instructions. Why cannot they be the basis of literature now? The veritable indispensables that they are, they should be carried with us all the time, imprinted in our memory, and, also displayed outside to build up a general public awareness, and hence, in need of constant circulation and percolation. Why cannot we have a new literary language in the present situation? Why can't we script a new literary plot where we can have words like 'sanitization', 'mask', 'avoid', 'distance' as our familiar everyday terms? Why cannot a new form of literature evolve where we can have a husband asking his wife, whether she has packed the bottle of the sanitizer, along with other essential stuffs into his bag; or, the wife reminding her husband to avoid crowded buses (which is advisable even in normal situation, but becomes imperative in the present condition)? Why cannot we have a collegegoing youth asking a question to a familiar face in his own locality, while riding on his own bi-cycle: "Hello sir, where is your mask"? Why cannot we have a middle-aged son asking his retired (approximately 65 years) dad to not go outside for purchasing paan from the nearby paan-shop, and, himself going instead? Also, another important factor that surfaces hereis that, during such Covid-infected phase there can be a sudden upsurge of practicing the regional/local/one's own literatures by the litterateurs or the non-litterateurs alike (over the global literatures),in various possible ways (by reading the classics and the masterpieces in abundance may be, or, by composing/trying to compose something, if the mood so permits; thereby contributing to its enrichment)which is quite obvious and understandable as well. For, it is but the 
natural tendency of all of us to talk in our own language, or, read something in that, or, express ourselves according to that socio-cultural-linguistic form, and, explore the unexplored avenues in it, if possible, because it is the language which is close to our heart, and it is the language with which we can find an instant attachment/attuning, more so in such troubled time like this. In a multilingual and multicultural country like ours, this growth of regional literatures can usher in a new era. Because, people in such crisis time tend to become least bothered about the global situation, and, focuses more on the country state own locality home surrounding, and, because of remaining confined at home talk mostly to his own family members, in his own mother-tongue apart from the rare going outs (that too for mere necessities like buying groceries, babyfoods, vegetables etc), or, working officially from home. So, home, and talking mostly in one's own mother-tongue become the obvious choice in such time.And, the promotion of the regional/local/topical is definitely an encouraging thing for any socio-linguistic background. But the important question is why cannot we rejoice at the unmasking of a new mode of literature which deals with the masked identities/faces roaming here and there; in markets, coffee-shops, in offices and restaurants, and, in general, outside; and, trying hard to get/go back to their protected homes as early as possible? Why cannot a new literature emanate out of this typical conflict between the inside home and the outside world, where the home is the veritable cocoon, the protective shelter vis-à-vis the Corona infected/affected outside world, the veritable other. Thus this new literature/s portrays the typical self-other binary/binarization which is prominent otherwise, but is now being carried to its extremity in the current situation. Also, this is the first time that we can experience that the names (Mr. 'X', 'Y', or ' $\mathrm{Z}$ ') becoming irrelevant; religiouscaste-gender identities becoming more and more vague, and, blurred, and, we are only getting reduced to certain 'masked' identity/identities. How should literature deal with these nameless, religionless, casteless, sexless (as it were) numerous 'masked' identities? Or, should literature rather focus more on this self-cocooned, self-protective, self-concerned, selfish individual, afraid to venture into the outside world, and wanting to sit more on the comfortable couch of the home safety; resulting in the birth ofsome sort of 'cave literature', or, 'room literature'/ 'home literature' generated by such 'self-protected' individuals? If that is so, then how would this 'cave literature'/ 'room literature' look like? What would be its forms and features? Should this mode of doing literature be encouraged by discouraging the various literatures that exhibit/manifest the dual tension of people having to go out and needing to come back amid the Corona pandemic? What sort of possibilities should the literature/s composed during, or, after the Covid-period direct us towards? Is it possible to include in these literatures the numerous sacrifices and selfless acts of the doctors and the police personnel in some way? Can it reflect the hue and cry of the beleaguered humanity? Can it attach a universal, cosmic touch by relating to the sufferings, agonies, and, miseries of the innumerable common people, the various private sector workers (who are losing jobs on an everyday basis), the daily labourers, and, most importantly, the migrant workers, who are the worst victims of the Covid-19 pandemic? Can it reflect the stifled cry of the child, playing with the blanket of her dead mother at Muzaffarpur railway station on 25th of May, 2020? Or, should it ignore it/brush it aside, considering the much-needed emphasis on selfprotection, and, self-preservation which are crucial in such time? But, can it simply overlook the fact that the self exists only in relation to the other? Can it relate to the tragedy of the sixteen migrant workers, who were killed by an empty freight train in Maharashtra's Aurangabad district, while sleeping on the railway track on the $9^{\text {th }}$ of May, 2020? Has literature got the ability to provide a human touch/humanistic touch to the death of 118 migrant workers during phase-III of the lockdown, or, to the deaths of the migrant workers happening everyday? Should literature instruct us to look at the troubled humanity, and the people in crisis from a moralistic, conscientious, humanistic viewpoint; needing to be reached at, or, be provided assistance for; or, should it rather teach us to view the migrant workers in an essentially sceptical way, as persons who are the sure harbingers of destruction for us, the apparently 'non-Coronated' people? So, should it help to foster this distance between the self and the other? Should literature reflect the phobia of the 'other', on the extra caring self, or,the home-cocooned/'shelfed' self?Should it sow the seeds of this lack of faith/trust and scepticism between humans; or, is it something not uncommon in literature:

\section{The Sea of Faith}

Was once, too, at the full, and round earth's shore

Lay like the folds of a bright girdle furl'd.

But now I only hear

Its melancholy, long, withdrawing roar,

Retreating, to the breath

Of the night wind, down the vast edges drear

And naked shingles of the world. (461) 
Can it prevent human beings from turning into animals, or, even worse than that, as it happened in the Palakkad district of Kerala on $27^{\text {th }}$ of May, when a pregnant elephant got killed after being fed by humans on pineapples laden with firecrackers/explosives? Does literature during, or, after the Covid-19, have to say that the world is essentially a bad place, and there is no love, no peace, or, certainty as has already been said by the Victorian poet Matthew Arnold already:

! for the world, which seems

To lie before us like a land of dreams,

So various, so beautiful, so new,

Hath really neither joy, nor love, nor light,

Nor certitude, nor peace, nor help for pain;

And we are here as on a darkling plain (461)

If the objective of literature during and after the Covid-19 is to promote and foster a certain type of self-obsessed, self-cocooned literature/s, then, is it something new? Can we attribute it only to the recent Covid pandemic? Aren't we introduced to it already by plays like Room by Harold Pinter where a wife (Rose) is expressing her apprehensions to her husband (Bert) about the residents residing at the basement of their building, because it is risky, troublesome, and, definitely not cosy:

I've never seen who it is. Who is it? Who lives down there? I'll have to ask. I mean, you might as well know, Bert. But whoever it is, it can't be too cosy. (8)

Or, elsewhere we find Rose expressing the same paranoia about the 'basement other':

Those walls would have finished you off. I don't know who lives down there now. Whoever it is, they're taking a big chance. Maybe they're foreigners. (9)

So, in view of the present scare of the 'basement other' we find Rose preferring the self-contained, self-preserving isolating comfort of her own room:

If they ever ask you, Bert, I'm quite happy where I am. We're quiet, we're all right. You're happy up here. It's not far up either, when you come in from outside. And we're not bothered. And nobody bothers us. (10)
Should this above statement of Rose be tagline of literature and culture in current times? Should the literature of the present times further promote this very notion of 'do not bother/do not disturb'? But if this notion is being carried to an extreme form, then it can have other discomforts as well. As, too much Corona-fear is making us sit at home to protect ourselves, this fear, when being carried to an extreme form, can result in the weakening of the self, and, division with one's near and dear ones (family members), by generating a general melancholic ill-temper, as happens in case of Jimmy Porter in Look Back inAnger(though Jimmy's case is different, and, he is mentioned only as a stray literary reference); who is disillusioned with everything possible in society and vents out his angry vituperations at his wife Alison, who has to bear with Jimmy's sour temper:

immy: I told you- pusillanimous. Do you know what it means?

\section{Cliff shakes his head.}

Neither did I really. All this time, I have been married to this woman, this monument to non-attachment, and suddenly I discover that there is actually a word that sums her up. Not just an adjective in the English language to describe her with — it's her name! Pusillanimous! It sounds like some fleshy Roman matron, doesn't it? The Lady Pusillanimous seen here with her husband Sextus, on their way to the Games. (16)

And, also we can have the exhaustion of Alison:

Alison: I don't think I want anything more to do with love. Any more. I can't take it on. (24)

\section{CONCLUSION}

So, too much of self-cocooning has got other demerits as well. Too much self-protection, self-absorption by social exclusion can result in a mental imbalance, a petulance, breeding of an ill-temper, and, mental depression (leading even to suicidal tendencies, as the suicide of Bollywood actor Sushant Singh Rajput proves a point; notwithstanding the fact that it is still disputed whether it is a murder or a suicide, and, we are only going by the official report) which is definitely not good. Should literature be able to deal with this other side/aspect of self-cocooning then, and the potential danger of making the selfish more selfish, or, should it rather, for fear of this, teach us more to go out/reach out to the other (which is also dangerous in such times); as is also discussed earlier? Also, what should be the new form of culture in such a socially distanced era? Would it have to undergo the same analytical change as 
literature? Regarding culture, things stand more problematic; especially in a multi-lingual, multi-regional country like India, which thrives on essential diversity, and cultural plurality/multiplicity, with no homogenous codification being possible. What can be the fruitful/effective way of observing the various cultural festivals/programmes across several cultures? How to observe the various big pujas (like Durgapuja in Bengali culture, Ganesh puja in Maharashtra etc) in such a time when we have to maintain social distancing compulsorily? Should the government take the stern decision to stop them for the time being? But would that not hurt thesentiments of the religious-minded, and, festival-oriented people of India? And, obviously, we cannot leave everything on law and administration. The role of self-alertness and selfconsciousness become crucial in such cases more than the actual police here. What should be the policy in place? The same also applies in case of marriage functions and other joyous festivals where we always can have the possibility of huge crowd. Is there an alternative possible way to observe them?

\section{REFERENCES}

[1] Green, David, ed. The Winged Word: An Anthology of Poems for Degree Course. Chennai: Macmillan, 2005. Print.

[2] Osborne, John. Look Back in Anger. London: Penguin, 2005. Print.

[3] Palgrave, Francis T. Golden Treasury of Songs and Lyrics. London: Macmillan, 1971. Print.

[4] Pinter, Harold. Celebration \&The Room. London: Faber and Faber, 2000. Print.

[5] Chaturvedi, Amit. "Maharashtra train accident: How 16 migrant labourers were killed". www.hindustantimes.com Hindustan Times, 8 May, 2020. Accessed 31 May, 2020.

[6] Khan, Fazil. "Mapping Accidents That Killed Over 100 Migrant Workers on Their Way to Home During Lockdown". www.news18.com. News18.com, 20 May, 2020. Accessed 4 June, 2020.

[7] Pratap, RishabhMadhavendra and Wells, Elizabeth. "Indian Actor Sushant Singh Rajput found dead in his Mumbai home". www.cnn.com. CNN, 15 June, 2020. Accessed 17 June, 2020

[8] Singh, Niyati. "Toddler tries to wake up dead mother at Bihar railway station". www.hindustantimes.com. Press Trust of India, 28 May, 2020. Accessed 6 June 2020.

[9] "Pregnant wild elephant dies in Kerala after cracker filled pineapple explodes in her mouth". www.thehindu.com. PTI, 5 June, 2020. Accessed 10 June, 2020.

[10] "In Theory Bakhtin: Dialogism, polyphony and Hetroglossia”. www.ceasefiremagazine.co.uk. 29 July, 2011. Accessed 8 June, 2020. 